\title{
Spatial and temporal distribution of cyanobacteria in Batticaloa Lagoon
}

Jalaldeen Mohamed Harris, ${ }^{1, *}$, Periyathamby Vinobaba ${ }^{1}$, Ranil Kavindra Asela Kularatne ${ }^{2,3}$, Ellawala Kankanamge Champika ${ }^{4}$

1. Department of Zoology, Eastern University, Vantharumoolai, Chenkaladi, Sri Lanka

2. MAS Capital (Private) Limited, 10th Floor, Aitken Spence Tower II, 315, Vauxhall Street, Colombo 2, Sri Lanka

3. MAS Active Trading (Pvt) Limited, No. 231, D.M. Colombage Mawatha, Nawala, Sri Lanka

4. Department of Civil and Environmental Engineering, Faculty of Engineering, University of Ruhuna, Hapugala, Galle, Sri Lanka

Received 11 August 2015

Revised 23 December 2015

Accepted 04 January 2016

\begin{abstract}
The necessity to understand the relationship between cyanobacterial species abundance and water quality variations in coastal lagoons is crucial to develop strategies to prevent further cyanobacterial proliferation. This paper evaluates the relationship between water quality variations on the distribution of cyanobacteria during a 12-month period in Batticaloa Lagoon (Sri Lanka) using Redundancy analysis and Pearson correlations. Drastic variations in $\mathrm{pH}$, temperature, salinity, dissolved oxygen (DO) and total phosphorus (TP) levels were reported, but not turbidity and $\mathrm{NO}_{3}{ }^{-}$. This brackish waterbody is hypereutrophic (TP levels $>0.1 \mathrm{mg} / \mathrm{L}$ ). The cyanobacterial community contained 13 genera and 22 species. $\mathrm{NO}_{3}{ }^{-}, \mathrm{TP}$ and turbidity levels positively influenced cyanobacterial abundance during all seasons indicating that nutrient (largely phosphorus) and sediment entry control is highly crucial along with periodic monitoring of cyanobacterial growth.
\end{abstract}

Keywords: Batticaloa Lagoon; cyanobacteria; nitrates $\left(\mathrm{NO}_{3}{ }^{-}\right)$; turbidity; total phosphorous (TP); water quality

* Corresponding author. E-mail: harriseusl@gmail.com 


\section{Introduction}

Batticaloa Lagoon (located between $7^{\circ} 58^{\prime} \mathrm{N}$ and $81^{\circ} 29^{\prime} \mathrm{E}$ to $7^{\circ} 20^{\prime} \mathrm{N}$ and $81^{\circ} 52^{\prime} \mathrm{E}$ ) is the third largest brackish water body in Sri Lanka with more than $90 \%$ of the area located in the Batticaloa District in the Eastern Province. The lagoon supports diverse ecosystems including marine habitats such as mangroves. However, due to poorly planned infrastructure development, aquaculture ponds and government security clearances the original mangrove cover of 1490 ha has been reduced to 321 ha at present during a 20 year period (IUCN Sri Lanka and the Central Environmental Authority, 2006; NECCDEP, 2010; Kularatne, 2014). Moreover, indiscriminate dumping of Municipal Solid Waste (MSW) by the local community and some local government authorities (e.g., Kattankudy Urban Council), disposal of untreated sewage, rice mill effluents, shrimp farm effluents and slaughterhouses effluents (e.g., in Urani area) tends to pollute the lagoon (Kularatne, 2014). Significant Pb contamination has been already reported by Kularatne (2014). Also occurrence of cyanobacteria (blue-green algae) (e.g., Microcystis aeruginosa, Oscillatoria sp., Lyngbya sp., Cylindrospermopsis sp., Nostoc sp. and Anabaena sp., etc.) have been reported by Harris and Vinobaba (2012a) indicating that there is some nutrient enrichment and further lagoon pollution is expected due to considerable anticipated unplanned developments in the Batticaloa area since the cessation of the ethnic conflict in May, 2009 (Kularatne, 2014).

Cyanobacteria secretes various cyanotoxins that are harmful to the biota. For example, Microcystis aeruginosa, Oscillatoria sp., Nostoc sp. and Anabaena sp. secrete microcystins (which are cyclic peptide hepatotoxins) that could cause death in mammals in acute doses by hypovolaemic shock (Codd et al., 1999; Falconer, 1999; Sathishkumar et al., 2010; Metcalf and Codd, 2012). Anabaena sp. as well as Lyngbya sp. and Cylindrospermopsis sp. secretes saxitoxins which are a group of about 30 neurotoxic carbamate alkaloids (Falconer, 1999; Metcalf and Codd, 2012). Moreover, odor attributed to the secretion of metabolites (example, 2methyl isoborneol and geosmin/trans-1,10-dimethyl-trans-9 decalol) is aesthetically unpleasing since tourism is an important commercial activity in the Batticaloa Lagoon. Also some species secrete skin irritants such as the phenolic bislactones aplysiatoxins (e.g., Oscillatoria sp. and Lyngbya sp.) and indole alkaloid lyngbyatoxins-A, -B and -C (e.g., Lyngbya sp.) (Falconer, 1999; Metcalf and Codd, 2012) which could be a concern to bathers in the lagoon.

There is a need to analyze cyanobacterial species and abundance variability in relation to water quality variations so that this information can be used to develop strategies to prevent 
further cyanobacterial growth. Redundancy analysis (RDA), a constrained linear ordination method has been used to evaluate the effects of environmental variables on freshwater cyanobacterial communities (Tian et al., 2012; Lu et al., 2013). In this study, we use RDA to evaluate the impact of seasonal variations of selected water quality parameters on the distribution of cyanobacteria in Batticaloa Lagoon.

\section{Materials and methods}

\subsection{Study area}

The 16 sampling points were previously defined based on the different biotypes in the lagoon (Fig. 1) and characteristics such as bottom substrate, surface, topography, depth, salinity and human impact level. The precise location of each station was determined using a portable GPS meter (Garmin, USA) (Table 1).

\subsection{Sampling and water quality analysis}

Water sampling was carried out during the period of March 2012 to February 2013 (i.e., twice a month) between 9 am and 11 am covering the different seasons. Period of November-February is the heaviest north-east monsoonal rainy period with intermittent or few showers occurring in the first inter-monsoonal period (March-April) and second inter-monsoonal period (SeptemberOctober). South-west monsoonal period (May-August) is the driest period in Batticaloa.

Samples were collected in triplicate by dipping well labeled sterilized plastic containers of $1000 \mathrm{~mL}$ to about $50 \mathrm{~cm}$ below the surface film. $\mathrm{pH}$, surface temperature, salinity and turbidity were analyzed in-situ using calibrated instruments (Hanna, Romania portable HI 98128 water proof $\mathrm{pH}$ meter for $\mathrm{pH}$ and temperature, Portable ATAGO, Japan, S/MillE Hand Refractometer for salinity and Hanna, Romania portable HI 93703 C turbidity meter for turbidity) as per standard methods (APHA, AWWA and WEF, 2005).

Water samples were kept in a cool, dark environment and carried to the laboratory for analysis of nutrients. Prior to nutrient analysis, water samples were filtered through GF/C filter papers to remove any green color interference of algae. Nitrates $\left(\mathrm{NO}_{3}{ }^{-}\right)$and phosphates as total phosphorous (TP) were measured within $48 \mathrm{hr}$ using the Molybdate Blue method and UV screening method, respectively (APHA, AWWA and WEF, 2005). Separate water samples were 
collected for dissolved oxygen (DO) analysis within $48 \mathrm{hr}$ using modified Winkler's Method (APHA, AWWA and WEF, 2005).

\subsection{Collection of cyanobacterial samples, identification and enumeration}

Cyanobacterial samples were also taken at each sampling point ( 5 samples per location) using a plankton net (Hydro-bios, Germany) with the end of the net having a collecting bottle with a capacity of $250 \mathrm{~mL}$. Cyanobacterial samples were collected slowly by horizontal hauling without causing disturbances to the cyanobacteria (at a distance of $10 \mathrm{~m}$ from the sampling vessel). The samples were immediately preserved using Lugol's solution (ratio is $1 \mathrm{~mL}$ of Lugol's solution to $100 \mathrm{~mL}$ of water sample) in order to settle the cyanobacteria and to get a clear view. The samples were then reduced to $10 \mathrm{~mL}$ by decanting the supernatant aliquot and centrifuged (Bench model D2230, Brand - Gallenkamp, UK) for $20 \mathrm{~min}$ at $4000 \mathrm{r} / \mathrm{min}$. One drop of concentrated sample was investigated under trinocular bright field research microscope (Labomed LX400, USA). Identification was done using standard keys (Prescott, 1970; Lee, 2008; Bellinger and Sigee, 2010) at 400 times magnification to lowest taxonomic level. The quantity of cyanobacteria was determined using $1 \mathrm{~mL}$ of sedimented sample through a Sedgewick-Rafter counting chamber (Pyser-SGI S50, UK) comprising a plastic cover glass (Pyser-SGI S51, UK) and then the number of individual species was counted as described in other reports (Littleford et al., 1940; Gilbert, 1942; Serfling, 1949).

The above processes were repeated 5 times and the mean was used to determine the sample abundance.

\subsection{Statistical analysis}

One-way ANOVA (unstacked) in Minitab Version 14 was used to evaluate any significant differences between the different seasons with reference to the mean levels of the different parameters analyzed.

All multivariate and ordination analyses were performed using CANOCO version 4.5. Firstly, Detrended correspondence analysis (DCA) was carried out and the first gradient length was used to select the appropriate model (ordination procedure) for the constrained ordinations. Redundancy analysis (RDA) was chosen as an appropriate tool for the analysis because the length of the ordination axes in DCA was less than 3 (Lepš and Šmilauer, 2003). The effects of 
environmental variables (i.e., $\mathrm{pH}$, temperature, salinity, turbidity, $\mathrm{DO}, \mathrm{NO}_{3}^{-}$and $\mathrm{TP}$ ) on cyanobacteria were analyzed and the environmental variables were taken up as the explanatory variables. All of these environmental variables were $\log (X+1)$ transformed before analysis (Tian et al., 2012; Lu et al., 2013). Co-variable, monsoon period was an ordinal variable introduced as the north-east monsoonal period=1, $1^{\text {st }}$ inter-monsoonal period $=2$, south-west monsoonal period $=3$ and $2^{\text {nd }}$ inter-monsoonal period $=4$ in the model. Monsoonal periods were assigned the number in the order of the monsoon periods occurring during the year. Twenty two cyanobacterial species were encountered in the lagoon. All species were incorporated into RDA. RDA was carried out on the data for all periods encountered during the study period. The results of RDA were visualized in the form of ordination diagrams in the Canodraw for Windows program. Species scores are represented as light colored arrows. Environmental variables are represented by dark bold arrows, pointing in the direction of maximal variation.

Pearson correlation analysis between cyanobacteria abundance and environmental factors were carried out. Levels of significance used were 5\% (significant) and 1\% (highly significant). Statistical analysis was carried out using the SPSS 16.0 statistical package.

\section{Results and discussion}

\subsection{Water quality of the study area}

Fig. 2 shows the temporal variations of the selected water quality parameters in Batticaloa Lagoon. Spatial variations of the selected water quality parameters are shown in Table S1.

Mean $\mathrm{pH}$ and temperature values reported in this study are in agreement with previous studies (GreenTec Consultants, 2009; Harris and Vinobaba, 2012b; Kularatne, 2014). pH was within the range of 6.0-8.5 to support estuarine and marine ecosystems (Svobodova et al., 1993; Harris and Vinobaba, 2012a, 2012b). However, significant $\mathrm{pH}$ and temperature variations $(P<$ 0.005) were evident between the different seasons with the lowest temperature and $\mathrm{pH}$ conditions reported during the heavy rainy periods of the north-east monsoon due to dilution effects (Harris and Vinobaba, 2012a; Jalal et al., 2012).

Mean salinity levels showed a significant seasonal variation $(P<0.005)$ with the lowest salinity scenarios reported during the north-east monsoonal period due to considerable dilution of the lagoonal waters by heavy surface and sub-surface runoff from the mainland (Coelho et al., 2007; Harris and Vinobaba, 2012b; Uzukwu et al., 2013; O'Neill et al., 2015). Highest salinity 
was evident at location 1 (Palameenmadu; northern bar mouth which is frequently breached by the fishermen to gain access to the Indian Ocean) and the lowest salinity levels were recorded at locations 11, 12 and 15. The entire lagoon including the southernmost sections could be described as a brackish water body (as salinity is between $0.5 \mathrm{~g} / \mathrm{L}$ and $30 \mathrm{~g} / \mathrm{L}$ ), though recent studies revealed that the northern basin becomes more saline with salinity levels exceeding 30 g/L during the driest spells (JUGAS Ltd, 2010; Kularatne, 2014) while other reports showed that the southernmost section is relatively fresh due to freshwater inflows (IUCN Sri Lanka and the Central Environmental Authority, 2006).

In contrast to previous reports (JUGAS Ltd, 2010), statistically there was no significant variation in the turbidity levels considering the different seasons $(P>0.005)$. Currently, in the Sri Lankan legislation, there is no ambient standard enacted or proposed for turbidity levels in inland waters and coastal waters.

The present study revealed that the mean $\mathrm{NO}_{3}{ }^{-}$levels were less than $5 \mathrm{mg} / \mathrm{L}$ which is the threshold limit for aquatic life (GreenTec Consultants, 2009) and there was no significant seasonal variation $(P>0.005)$. In contrast, mean TP levels showed a significant seasonal variation $(P<0.005)$ with most of the locations (i.e., locations 1, 2, 4, 5, 6, 9, 10, 12, 15 and 16) showing elevated levels during the second inter-monsoonal season and then during the north-east monsoonal period. This is possibly due to runoff entry from agricultural lands, urban areas and shrimp farms, etc. TP levels were in excess of $0.010 \mathrm{mg} / \mathrm{L}$ to favor the growth of cyanobacteria and the fact that the TP levels have well exceeded $0.1 \mathrm{mg} / \mathrm{L}$, indicates that Batticaloa Lagoon is hypereutrophic (OECD, 1982; Masters, 2000; Weiner and Matthews, 2012; Mallick, 2014).

All the locations reported DO values higher than $4.5 \mathrm{mg} / \mathrm{L}$, which is sufficient for the survival of fish and other lagoonal biota (GreenTec Consultants, 2009). Almost all the locations reported the lowest DO levels during the north-east monsoonal period $(P<0.005)$, possibly due to the low photosynthetic activities of the cyanobacteria during the cloudy rainy periods (Uzukwu et al., 2013).

\subsection{Cyanobacterial species composition}

A total of 60 species of phytoplankton were reported (data not shown) out of which there were 22 species of cyanobacteria from 5 different Orders (Table 2). The most abundant cyanobacteria in this lagoon were bloom or colony-forming genera (Microcystis and Anabaena) as well as the 
solitary filamentous genera Cylindrospermopsis and Oscillatoria. Among these cyanobacteria genera, Microcystis aeruginosa, Spirulina major, Anabaena oscillarioides, Cylindrospermopsis sp., Lyngbya sp. and Oscillatoria sancta lacked seasonality in all seasons and were the main representatives of the cyanobacterial community. Throughout the study period, Anabaena oscillarioides seemed to be more dominant (17.1\%), followed by Oscillatoria sancta (13\%), Microcystis aeruginosa (11\%) and then Spirulina major (10.2\%). Chroococcales peak density was observed during the north-east monsoon period while Glaucocystales and Nostocales during the first inter-monsoon. Oscillatoriales and Synechococcales were predominant during the southwest monsoonal period. Microcystis aeruginosa and Anabaena sp. are bloom-forming species (Tian et al., 2012; Lu et al., 2013) and both these species along with Oscillatoria sp. secrete microcystins (Rapala et al., 1997; Codd et al., 1999; Falconer, 1999; Sathishkumar et al., 2010; Metcalf and Codd, 2012). Anabaena sp. also secretes saxitoxins and Oscillatoria sp. produce phenolic bislactones aplysiatoxins (Falconer, 1999; Metcalf and Codd, 2012). Studies conducted by $\mathrm{Lu}$ et al. (2013) for freshwater lakes have revealed that Anabaena sp., Oscillatoria sp. and Cylindrospermopsis sp. have the ability to fix atmospheric $\mathrm{N}_{2}$.

\subsection{Variations in abundance and species composition}

Fig. 3 shows the spatial variation and the temporal variation of cyanobacterial composition in Batticaloa Lagoon, respectively.

Cyanobacterial abundance in Batticaloa Lagoon exhibited distinct spatial distribution. Highest abundance was recorded during the $1^{\text {st }}$ inter-monsoonal period (March to April) and low values during the $2^{\text {nd }}$ inter-monsoon period (September to October). The maximum individual cyanobacteria cell was observed in the month of April $2013\left(7.86 \times 10^{6}\right.$ cells/L), the lowest density occurred in September $2013\left(3.29 \times 10^{6}\right.$ cells/L). Spatial variation of cyanobacterial composition showed heterogeneity among the sampling sites. During the study period only location 11 had all five orders while sites 9 and 13 were solely represented by Oscillatoria sancta.

Peak numerical abundance of Microcystis aeruginosa population reached during the northeast monsoonal period with a cell density of $1.07 \times 10^{6}$ cells/L. However, this organism again became prevalent during late March in the first inter-monsoon period. During mid-April conditions became optimal for the growth of the Microcystis and a very rapid development towards the latter part of the month. Cylindrospermopsis sp. reached maximum in April (first 
inter-monsoon) with a density of $0.52 \times 10^{6}$ cells/ $\mathrm{L}$ while during the other seasons abundance was more or less the same.

\subsection{Impact of water quality variations on cyanobacterial species and their abundance}

Fig. 4 shows the first two axes of RDA for the selected water quality parameters associated with the cyanobacteria variation in all periods investigated and during the different seasons. Table 3 shows the summary of RDA between the selected water quality parameters and cyanobacterial abundance in Batticaloa Lagoon.

When all periods in the year are analyzed, the eigen values $(\lambda)$ for RDA axis $1(\lambda: 0.212)$ and RDA axis $2(\lambda$ : 0.035$)$ explained $24.7 \%$ of variance in the species data. Variables such as salinity ( $r=-0.7543)$, DO $(r=-0.2506)$, turbidity $(r=0.3299)$ and $\mathrm{NO}_{3}{ }^{-}(r=0.3556)$, related to axis 1 while turbidity $(r=0.2388)$, TP $(r=0.2618)$, temperature $(r=-0.3275)$ and $\mathrm{pH}(r=-0.3647)$ associated with axis 2 . The RDA ordination diagram clearly shows that different cyanobacterial species have correlations with different water quality parameters. Almost all cyanobacterial species observed in Batticaloa Lagoon negatively correlated with salinity and DO while they positively correlated with $\mathrm{NO}_{3}{ }^{-}, \mathrm{TP}$, turbidity and temperature. Microcystis, Arthrospira, Nostoc, Anabaena, Lyngbya and Aphanothece sp. strongly positively correlated with turbidity, $\mathrm{NO}_{3}{ }^{-}$and TP. General water quality and purity of water is affected by the abundance of that group. Oscillatoria strongly positively correlated with $\mathrm{pH}$. During the north-east monsoonal period (wettest period) among the 22 species found in the lagoon only 12 species were abundant. During

the south-west monsoonal period (driest period) abundance of cyanobacterial species were high compared with the other periods. Monsoonal period accounted for $2.9 \%$ of the variations observed in the species data.

Generally, temperature is a limiting factor for cyanobacterial growth (Hansson, 1996; Lu et al., 2013). Temperature beyond $15^{\circ} \mathrm{C}$ is considered as the threshold value (Hansson, 1996; Lu et al., 2013). However, in Sri Lanka temperature throughout the year is far exceeding $15^{\circ} \mathrm{C}$. Therefore, temperature is not a limiting factor for cyanobacterial growth in countries such as Sri Lanka; Batticaloa District occurs within the Dry Zone of Sri Lanka and the total annual mean rainfall is $1704.7 \mathrm{~mm}$, annual mean daily maximum and minimum temperatures are 30.6 and $24.3^{\circ} \mathrm{C}$, respectively. 
Although high turbidity levels are known to suppress cyanobacterial growth by decreasing light penetration for photosynthesis, this study showed a positive relationship between cyanobacterial abundance and turbidity during all periods of investigation. Turbidity is mostly governed by the amount of total suspended solids in the water, but algae and organic detritus particles derived from bloom decay together with co-occurring bacteria can cause further increase in water turbidity ( $\mathrm{Lu}$ et al., 2013). It is likely that phosphates and $\mathrm{NH}_{4}{ }^{+}$ions adsorbed to suspended sediments and nutrients and dissolved organic carbon (DOC) released during algae and detritus decay may favor cyanobacterial proliferation. Some cyanobacterial species have an ability to acquire both $\mathrm{N}$ and $\mathrm{C}$ via particle ingestion or by the uptake of DOC (Anderson et al., 2002). It has also been documented that some cyanobacteria (example, Microcystis sp.) could make vertical movements to the water surface by regulating their buoyancy within the water column through intracellular gas vacuoles; in this way such cyanobacterial species can thrive by obtaining enough light under high turbidity or low light penetration conditions while enhancing their dominance by inhibiting the growth of other algae (Reynolds et al., 1987; Anderson et al., 2002; Su et al., 2014).

All species negatively correlated with salinity, but positively correlated with $\mathrm{NO}_{3}{ }^{-}$and $\mathrm{TP}$ levels. Generally, higher phosphorous (P) levels are known to favor cyanobacteria (Fong et al., 1993; Kuffner and Paul, 2001; Anderson et al., 2002).

In analyzing Pearson correlations the same trends were observed in RDA ordination diagrams. However, it should be noted that Pearson correlations between any species and $\mathrm{NO}_{3}{ }^{-}$, $\mathrm{TP}$ and $\mathrm{pH}$ is not significant (Table 4).

\subsection{Implications of this study in the management of the lagoon}

Since this study elucidates a positive relationship between nutrient levels ( $\mathrm{NO}_{3}{ }^{-}$and $\mathrm{TP}$ levels), turbidity and cyanobacterial abundance in brackish waterbodies such as Batticaloa Lagoon, development and implementation of a comprehensive nutrient management strategy (largely focusing on P) and sediment entry control is of paramount importance. Controlling internal loading of $\mathrm{P}$ requires considerable attention since many cyanobacteria such as Anabaena sp., Oscillatoria sp. and Cylindrospermopsis sp. have the ability to fix atmospheric $\mathrm{N}_{2}$ (Lu et al., 2013) and hence $\mathrm{NO}_{3}{ }^{-}$or any other nitrogenous material is not a limiting factor for cyanobacterial growth in general (Sharply and Wang, 2014). Nutrient management and sedimentation 
controlling strategies need to include restoration of the remaining mangrove stands along with bank erosion control and stabilization (Sharply and Wang, 2014), replantation of mangroves where possible, construction of free-water surface wetlands in canals leading to the lagoon to trap total suspended solids (TSS) and nutrient-laden runoff (Boonsong et al., 2002) and proper landuse planning and management by means of preventing further degradation of the lagoon and its surroundings (example, aquaculture ponds and disposal of effluents including treated effluents to the lagoon).

Simultaneously, there is a need to regularly monitor the growth of different cyanobacterial species and cyanotoxins produced by the identified species. Also removing cyanobacteria and cyanotoxins is an important step in the recovery and protection of the lagoon. The use of algaecides (example, $\mathrm{Cu}$ salts) is not advisable since cell lysis would further release cyanotoxins and the algaecides would be toxic to other biota too. Recently, peat was discovered to have a potential to be used as an adsorbent for the removal of microcystins (Sathishkumar et al., 2010). Other studies have focused on dephosphoriation of $\mathrm{P}$ rich waters using various coagulants; example poly ferric chloride, poly aluminum chloride and poly ferric aluminum chloride with polyacrylamide (Yong et al., 2011). However, removal of cyanobacteria and cyanotoxins from brackish waterbodies and dephosphoriation warrants detailed investigations when dealing with large waterbodies.

\section{Conclusions}

Batticaloa Lagoon is a brackish waterbody showing significant seasonal variations in the $\mathrm{pH}$, temperature, salinity and DO (with lowest values occurring during the heavy rainy periods of the north-east monsoon). TP levels also showed a drastic seasonal variation and the lagoon is hypereutrophic with levels far exceeding $0.1 \mathrm{mg} / \mathrm{L}$. However, no significant seasonal variation in turbidity and $\mathrm{NO}_{3}{ }^{-}(<5 \mathrm{mg} / \mathrm{L}$ in almost all the locations $)$ levels was evident.

13 genera and 22 species of cyanobacterial were identified in Batticaloa Lagoon. $\mathrm{NO}_{3}{ }^{-}$, TP and turbidity levels were the key drivers to influence cyanobacterial abundance irrespective of the seasons. Therefore, nutrient (largely P) and sediment entry control to the lagoon is highly crucial along with periodic monitoring of cyanobacterial growth. 


\section{Acknowledgments}

This work was supported by the National Science Foundation of Sri Lanka (RG/2011/ES/04). Furthermore, we thank the personnel who assisted us during the field works. We also thank two anonymous reviewers for their valuable comments and suggestions, which enabled us to drastically improve our manuscript.

\section{Appendix A. Supplementary data}

Supplementary data to this article can be found online at.

\section{References}

Anderson, D.M., Glibert, P.M., Burkholder, J.M., 2002. Harmful algal blooms and eutrophication: nutrient sources, composition, and consequences. Estuaries 25, 704-726.

APHA, AWWA, WEF, 2005. Standard Methods for the Examination of Water and Wastewater $\left(21^{\text {th }}\right.$ Ed.). American Public Health Association/American Water Works Association/Water Environment Federation, Washington D.C., USA.

Bellinger, E.G., Sigee, D.C., 2010. Freshwater Algae, Identification and Use as Bioindicators. Wiley-Blackwell Publications, UK.

Boonsong, K., Piyatiratitivorakul, S., Patanapolpaiboon, P., 2002. The use of a mangrove plantation as a constructed wetland for municipal wastewater treatment. J. Sci. Res. Chula. Univ. 27, 43-58.

Codd, G.A., Bell, S.G., Kaya, K., Ward, C.J., Beattie, K.A., Metcalf, J.S., 1999. Cyanobacterial toxins, exposure routes and human health. Eur. J. Phycol. 34, 405-415.

Coelho, S., Gamito, S., Pérez-Ruzafa, A., 2007. Trophic state of Foz de Almargem coastal lagoon (Algarve, South Portugal) based on the water quality and the phytoplankton community. Estuar. Coast. Shelf Sci. 71, 218-231.

Falconer, I.R., 1999. An overview of problems caused by toxic blue-green algae (cyanobacteria) in drinking and recreational water. Environ. Toxicol. 14, 5-12.

Fong, P., Zedler, J.B., Donohoe, R.M., 1993. Nitrogen vs. phosphorus limitation of algal biomass in shallow coastal lagoons. Limnol. Oceanogr. 38, 906-923. 
Gilbert, J.Y., 1942. The errors of the Sedgwick-Rafter counting chamber in the enumeration of phytoplankton. Trans. Am. Microsc. Soc. 61, 217-226.

GreenTec Consultants, 2009. Seasonal Variation in Water Quality in Batticaloa Lagoon, including the Identification of the most likely Sources of Key Pollutants Assayed and Recommendations to Improve the Future Water Quality in the Lagoon. Final Report, pp. 80, Annexure 6, May 2010, NEC/PO/TECS(II)/08/05, NECCDEP/GreenTec Consultants, ADB Loan 2027 Sri (SF): North East Coastal Community Development Project (NECCDEP).

Hansson L.A., 1996. Algal recruitment from lake sediments in relation to grazing, sinking, and dominance patterns in the phytoplankton community. Limnol. Oceanogr. 41, 1312-1323.

Harris, J.M., Vinobaba, P., 2012a. Impact of water quality on species composition and seasonal fluctuation of planktons of Batticaloa lagoon, Sri Lanka. J. Ecosyst. Ecogr. 2, 1-6.

Harris, J.M., Vinobaba, P., 2012b. Seasonal influence of water quality of Batticaloa Lagoon, Sri Lanka on fish and plankton abundance. Int. J. Environ. Sci. 3, 371-385.

IUCN Sri Lanka and the Central Environmental Authority, 2006. National Wetland Directory of Sri Lanka. International Union for the Conservation of Nature, Central Environmental Authority and International Water Management Institute, Colombo, Sri Lanka.

Jalal, K.C.A., Kamaruzzaman, B.Y., Arshad, A., Ara, R., Rahman, M.F., 2012. Diversity and distribution of fishes in tropical estuary Kuantan, Pahang, Malaysia. Pak. J. Biol. Sci. 15, $576-582$.

JUGAS Ltd, 2010. A Participatory Assessment of the Dynamics, Seasonal Variation and Current Status of Fishery in Batticaloa Lagoon. Final Draft Report. pp 126, Annexure 8, September 2010. NEC/PO/TEC/TECH (II) 08/08. NECCDEP/ JUGAS Professional Services (Pvt.) Ltd. ADB Loan Sri (SF): North East Coastal Community Development Project.

Kuffner, I.B., Paul, V.J., 2001. Effects of nitrate, phosphate and iron on the growth of macroalgae and benthic cyanobacteria from Cocos Lagoon, Guam. Mar. Ecol. Prog. Ser. 222, 63-72.

Kularatne, R.K.A., 2014. Phytoremediation of Pb by Avicennia marina (Forsk.) Vierh and spatial variation of $\mathrm{Pb}$ in the Batticaloa Lagoon, Sri Lanka during driest periods: A field study. Int. J. Phytoremediation 16, 509-523.

Lee, R.E., 2008. Phycology ( $4^{\text {th }}$ Ed.). Cambridge University Press, UK.

Lepš, J., Šmilauer, P., 2003. Multivariate Analysis of Ecological Data using CANOCO. Cambridge University Press, Cambridge, UK. 
Littleford, R.A., Newcombe, C.L., Shepherd, B.B., 1940. An experimental study of certain quantitative plankton methods. Ecology 21, 309-322.

Lu, X., Tian, C., Pei, H., Hu, W., Xie, J., 2013. Environmental factors influencing cyanobacteria community structure in Dongping Lake, China. J. Environ. Sci. 25, 2196-2206.

Mallick, A., 2014. Environmental Science and Management. Viva Books Private Limited, New Delhi, India.

Masters, G.M., 2000. Introduction to Environmental Engineering and Science ( $4^{\text {th }}$ Ed.). PrenticeHall, New Delhi, India.

Metcalf, J.S., Codd, G.A., 2012. Cyanotoxins. In Ecology of Cyanobacteria II: Their Diversity in Space and Time (Whitton B.A., Ed.). Springer Science+Business Media B.V. 651-675.

NECCDEP, 2010. Batticaloa Lagoon Special Area Management Plan "BL SAM". Final. pp.125. January 2010. Eastern Province Integrated Coastal Resources Management Plan (EP ICRMP) 2010-2013. The Green Blue Sunrise Plan. ANZDEC Ltd., Resource Development Consultants. ADB LOAN 2027 SRI (SF): North East Coastal Community Development Project (NECCDEP).

OECD, 1982. Eutrophication of Waters Monitoring and Control. Organization for Economic Cooperation and Development, Paris.

O'Neill, K., Schreider, M., McArthur, L., Schreider, S., 2015. Changes in the water quality characteristics during a macroalgal bloom in a coastal lagoon. Ocean Coast. Manage. 118, Part A, 32-26.

Prescott, G.W., 1970. How to Know the Fresh Water Algae. W.M.C. Brown Company Publishers, Iowa, USA.

Rapala, J., Sivonen, K., Lyra, C., Niemela, S.I., 1997. Variation of microcystins, cyanobacterial hepatotoxins, in Anabaena spp. as a function of growth stimuli. Appl. Environ. Microbiol. 63, 2206-2212.

Reynolds, C.S., Oliver, R.L., Walsby, A.E., 1987. Cyanobacterial dominance: the role of buoyancy regulation in dynamic lake environments. New Zeal. J. Mar. Fresh. Res. 21, 379390.

Sathishkumar, M., Pavagadhi, S., Mahadevan, A., Balasubramanian, R., Burger, D.F., 2010. Removal of a potent cyanobacterial hepatotoxin by peat. J. Environ. Sci. Health A Tox. Hazard. Subst. Environ. Eng. 45, 1877-1884. 
Serfling, R.E., 1949. Quantitative estimates of plankton from small samples of Sedgwick-Rafter cell mounts of concentrate samples. Trans. Am. Microsc. Soc. 68, 185-199.

Sharply, A., Wang, X., 2014. Managing agricultural phosphorus for water quality: lessons from the USA and China. J. Environ. Sci. 26, 1770-1782.

Su, M., Yu, J., Pan, S., An, W., Yang, M., 2014. Spatial and temporal variations of two cyanobacteria in the mesotrophic Miyun reservoir, China. J. Environ. Sci. 26, 289-298.

Svobodova, Z., Lloyd, R., Machova, J., Vykusova, B., 1993. Water Quality and Fish Health. EIFAC Technical Paper, 54. Food and Agriculture Organization of the United Nations. Rome, Italy.

Tian, C., Pei, H., Hu, W., Xie, J., 2012. Variation of cyanobacteria with different environmental conditions in Nansi Lake, China. J. Environ. Sci. 24, 1394-1402.

Uzukwu, P.U., Aranyo, A.A., Uzukwu, C.O., 2013. Relationship among Tilapia guineensis fingerlings abundance and water quality variations in a brackish water reservoir in Lagos. J. Fish. Aquat. Sci. 8, 257-260.

Weiner, R.F., Matthews, R., 2012. Environmental Engineering ( $4^{\text {th }}$ Ed.). Butterworth-Heinemann, Elsevier, India.

Yong, M., Haihong, Z., Ming, L., Lihua, H., Feiping, Z., Dulin, Y., 2011. Removal of phosphorus from organic wastewater by ACPAM-inorganic flocculant coagulation. Ind. Water Treatment 31, 35-38. 


\section{Figures legend}

Fig. 1 Map of the study area showing the sampling locations. Locations 1, 2, 3, 4, 5, 6, 7, 8, 9, 10, 11, 12, 13, 14, 15 and 16 denotes Palameenmadu, Kallady, Kottamunai, Eravur, Sathurukkondan, Thiruperumthurai, Urani, Valayaravu, Vavunativu, Kattankudy, Kaluthawalai, Chettipalayam, Kallaru, Kallaru stream, Pattiruppu and Kokkaticholai, respectively.

Fig. 2 Temporal variation of (a) temperature and $\mathrm{pH}$, (b) turbidity and salinity, (c) Nitrate and TP and (d) DO in Batticaloa Lagoon during the study period (March 2012 to February 2013). Each data point represents the mean value of 16 sampling locations.

Fig. 3 Spatial (a) and temporal (b) variation of cyanobacterial composition in Batticaloa Lagoon. SW, NE, IM1 and IM2 denotes south-west monsoon, north-east monsoon, 1st inter-monsoon and 2nd inter-monsoon, respectively.

Fig. 4 The first two axes of RDA for environmental factors associated with the cyanobacteria variation during the study period at Batticaloa Lagoon (monsoon period is considered as a covariable in the analysis). Aph.: Aphanothece sp., Chr.: Chroococcus sp., Mic.: Microcystis sp., Spi.: Spirulina sp., Gla.: Glaucocystis sp., Ana.: Anabaena sp., Anab.: Anabaenopsis sp., Cyl.: Cylindrospermopsis sp., Nostoc: Nostoc sp., Art.: Arthrospira sp., Lyn.: Lyngbya sp., Osc.: Oscillatoria sp., Mer.: Merismopedia sp. 


\section{JES-D-15-01606 Graphical Abstract}
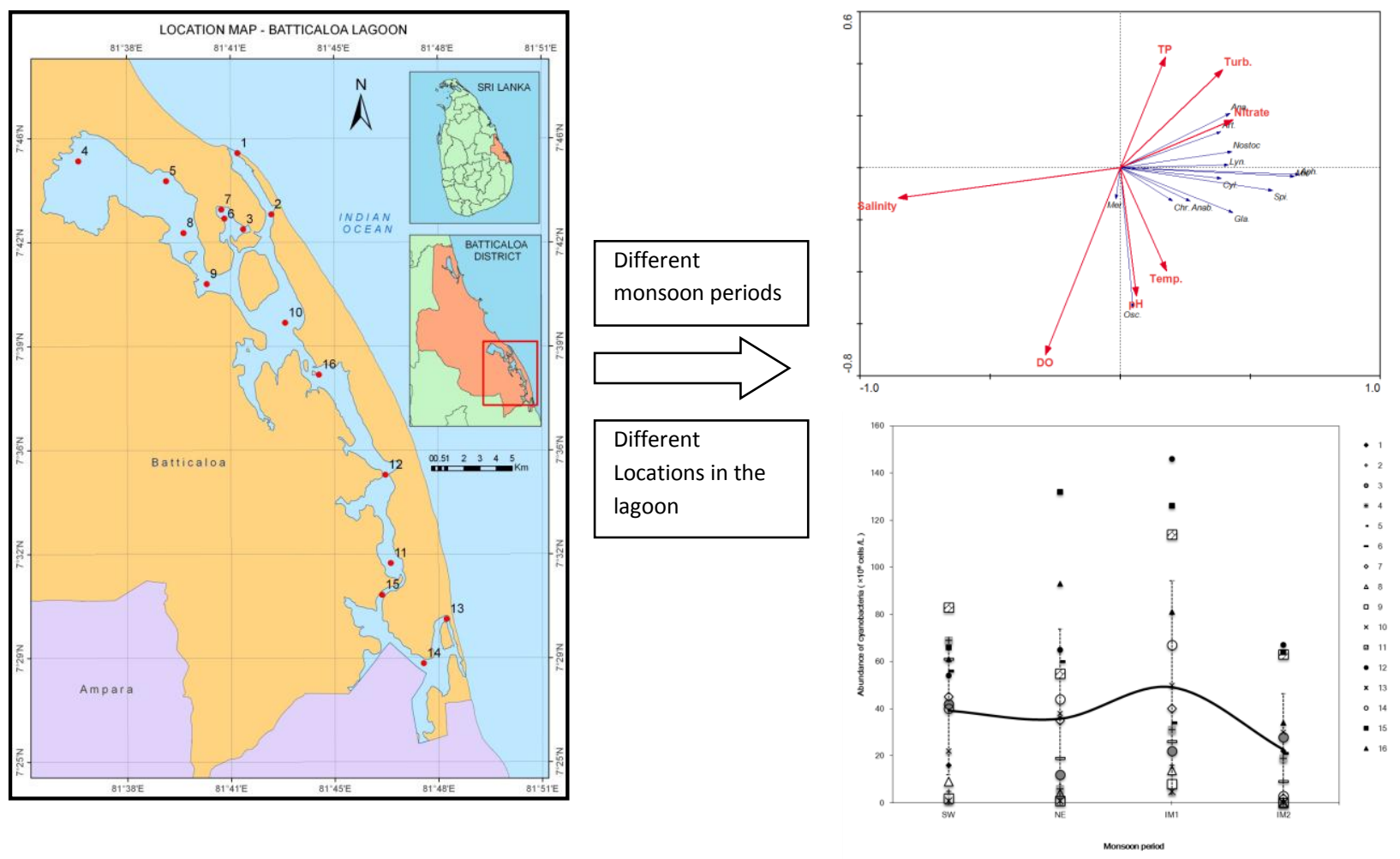


\section{JES-15-01606 List of tables}

Table 1 Brief description of the study area with the GPS coordinates

\begin{tabular}{|c|c|c|}
\hline Location & $\begin{array}{l}\text { GPS } \\
\text { Coordinates }\end{array}$ & Remarks \\
\hline 1 Palameenmadu & $\begin{array}{l}7^{\circ} 45^{\prime} 29.58^{\prime \prime} \mathrm{N} \\
81^{\circ} 41^{\prime} 14.39^{\prime \prime} \mathrm{E}\end{array}$ & $\begin{array}{l}\text { Located close to the bar mouth and opens to the Indian } \\
\text { Ocean when breached during rainy periods. Characterized } \\
\text { by a muddy substrate. }\end{array}$ \\
\hline 2 Kallady & $\begin{array}{l}7^{\circ} 43^{\prime} 23.42^{\prime \prime} \mathrm{N} \\
81^{\circ} 42^{\prime} 29.93^{\prime \prime} \mathrm{E}\end{array}$ & $\begin{array}{l}\text { Fairly high saline water with suitable spawning ground for } \\
\text { Sea bass. }\end{array}$ \\
\hline 3 Kottamunai & $\begin{array}{l}7^{\circ} 42^{\prime} 58.15^{\prime \prime} \mathrm{N} \\
81^{\circ} 41^{\prime} 48.64^{\prime \prime} \mathrm{E}\end{array}$ & $\begin{array}{l}\text { Freshwater area that is highly organically enriched. } \\
\text { Substratum profile is characterized by fine muddy silt with } \\
\text { abundance of aquatic vegetation. Located near a sewage } \\
\text { outfall. }\end{array}$ \\
\hline 4 Eravur & $\begin{array}{l}7^{\circ} 45^{\prime} 14.81^{\prime \prime} \mathrm{N} \\
81^{\circ} 35^{\prime} 51.45^{\prime \prime} \mathrm{E}\end{array}$ & $\begin{array}{l}\text { Located near a sewage outfall. Highest levels of industrial } \\
\text { pollution are likely. }\end{array}$ \\
\hline $\begin{array}{l}5 \\
\text { Sathurukkondan }\end{array}$ & $7^{\circ} 44^{\prime} 31.96^{\prime \prime} \mathrm{N}$ & $\begin{array}{l}\text { Pristine mangrove areas that have been recommended to be } \\
\text { declared as a sanctuary as these marshy lands provides } \\
\text { habitats for several species of birds including migrant } \\
\text { waders and rare species such as Lesser Adjutant Stork } \\
\text { Leptoptilus javanicus and Spot Billed Pelican Pelecanus } \\
\text { philippensis (NECCDEP, 2009). }\end{array}$ \\
\hline $\begin{array}{l}6 \\
\text { Thiruperumthurai }\end{array}$ & $\begin{array}{l}7^{\circ} 43^{\prime} 12.39^{\prime \prime} \mathrm{N} \\
81^{\circ} 42^{\prime} 16.24^{\prime \prime} \mathrm{E}\end{array}$ & $\begin{array}{l}\text { Located near a shrimp farming site on the northern sector } \\
\text { with sandy substrate. }\end{array}$ \\
\hline 7 Urani & $\begin{array}{l}7^{\circ} 43^{\prime} 07.22^{\prime \prime} \mathrm{N} \\
81^{\circ} 41^{\prime} 20.27^{\prime \prime} \mathrm{E}\end{array}$ & $\begin{array}{l}\text { Highest levels of industrial pollution are likely. } \\
\text { Contaminated with shrimp farm effluents and } \\
\text { slaughterhouses effluents. }\end{array}$ \\
\hline
\end{tabular}


8 Valayaravu

$7^{\circ} 42^{\prime} 48.07^{\prime \prime} \mathrm{N}$

$81^{\circ} 39^{\prime} 24.88^{\prime \prime} \mathrm{E}$

9 Vavunativu

$7^{\circ} 41^{\prime} 45.15^{\prime \prime} \mathrm{N}$

$81^{\circ} 39^{\prime} 36.73^{\prime \prime} \mathrm{E}$

10 Kattankudy $\quad 7^{\circ} 39^{\prime} 38.64^{\prime \prime} \mathrm{N}$

$81^{\circ} 43^{\prime} 59.98^{\prime \prime} \mathrm{E}$

11 Kaluthawalai $\quad 7^{\circ} 32^{\prime} 39.57^{\prime \prime} \mathrm{N}$

$81^{\circ} 46^{\prime} 29.62^{\prime \prime} \mathrm{E}$

12 Chettipalayam $7^{\circ} 43^{\prime} 07.22^{\prime \prime} \mathrm{N}$

$81^{\circ} 41^{\prime 2} 20.27^{\prime \prime} \mathrm{E}$

13 Kallaru

$7^{\circ} 29^{\prime} 47.36^{\prime \prime} \mathrm{N}$

$81^{\circ} 48^{\prime} 27.36^{\prime \prime} \mathrm{E}$

14 Kallaru stream $\quad 7^{\circ} 28^{\prime} 19.08^{\prime \prime} \mathrm{N}$

$81^{\circ} 47^{\prime} 30.81^{\prime \prime} \mathrm{E}$

15 Pattiruppu

$7^{\circ} 30^{\prime} 32.08^{\prime \prime} \mathrm{N}$

$81^{\circ} 46^{\prime} 15.29^{\prime \prime} \mathrm{E}$

16 Kokkaticholai $\quad 7^{\circ} 38^{\prime} 01.17^{\prime \prime} \mathrm{N}$ characterized by fine muddy silt with abundance of aquatic vegetation.

Highest levels of industrial pollution are likely. Freshwater area that is highly organically enriched. Substratum profile Muddy bottom with aquatic moss.

Sandy bottom near to sewage disposal.

Subjected to fertilizer and pesticide runoff from nearby crop lands.

Located near a sewage outfall.

Located close to the bar mouth and opens to the Indian Ocean when breached during rainy periods. Characterized by a muddy substrate.

Located near a sewage outfall.

Completely fresh water area and highly turbid with the abundance of Eichhornia crassipes (water hyacinth).

Subjected to agricultural runoff with muddy bottom. 
Table 2 List of cyanobacterial species recorded from the Batticaloa Lagoon

\begin{tabular}{|c|c|c|}
\hline Order & Genera & Species \\
\hline \multirow[t]{7}{*}{ Chroococcales } & Aphanothece & Aphanothece sp. \\
\hline & Chroococcus & Chroococcus sp. \\
\hline & Microcystis & Microcystis aeruginosa \\
\hline & & Microcystis sp2. \\
\hline & Spirulina & Spirulina major \\
\hline & & Spirulina princeps \\
\hline & & Spirulina subsalsa \\
\hline Glaucocystales & Glaucocystis & Glaucocystis sp. \\
\hline \multirow[t]{7}{*}{ Nostocales } & Anabaena & Anabaena oscillarioides \\
\hline & & Anabaena sp2. \\
\hline & Anabaenopsis & Anabaenopsis arnoldii \\
\hline & & Anabaenopsis sp1. \\
\hline & & Anabaenopsis sp2. \\
\hline & Cylindrospermopsis & Cylindrospermopsis sp. \\
\hline & Nostoc & Nostoc sp. \\
\hline \multirow[t]{5}{*}{ Oscillatoriales } & Arthrospira & Arthrospira maxima \\
\hline & & Arthrospira sp2. \\
\hline & Lyngbya & Lyngbya sp. \\
\hline & Oscillatoria & Oscillatoria sancta \\
\hline & & Oscillatoria sp2. \\
\hline \multirow[t]{2}{*}{ Synechococcales } & Merismopedia & Merismopedia glauca \\
\hline & & Merismopedia sp2. \\
\hline
\end{tabular}


Table 3 Summary of RDA between environmental factors and cyanobacterial abundance in Batticaloa Lagoon during the entire period of study (monsoon periods have been considered as a covariate in the analysis)

\begin{tabular}{llc}
\hline Axis & 1 & 2 \\
\hline Eigen values & 0.212 & 0.035 \\
Species-environment correlations & 0.809 & 0.613 \\
Cumulative percentage variance of species data & 21.9 & 25.5 \\
Cumulative percentage variance of species-environment relation & 72.3 & 84.3 \\
Sum of all unconstrained Eigen values & 0.971 \\
Sum of all canonical Eigen values & 0.294 \\
\hline
\end{tabular}

In the model, 1: monsoon period was coded as the north-east monsoon period, 2: $1^{\text {st }}$ intermonsoonal period, 3: south-west monsoon period and 4: $2^{\text {nd }}$ inter-monsoonal period 
Table 4 Pearson correlation coefficients between the selected parameters during all periods investigated

\begin{tabular}{|c|c|c|c|c|c|c|c|}
\hline Cyanobacterial species & Salinity & $\mathrm{DO}$ & Turbidity & Nitrates & $\mathrm{TP}$ & Temperature & $\mathrm{pH}$ \\
\hline Aphanothece sp. & $-0.650^{* *}$ & -0.451 & $0.761^{* *}$ & 0.42 & 0.429 & 0.586 & 0.102 \\
\hline Chroococcus sp. & -0.184 & 0.062 & -0.142 & -0.063 & -0.113 & -0.031 & -0.041 \\
\hline Microcystis aeruginosa & -0.41 & $-0.446^{*}$ & $0.628^{* *}$ & 0.197 & 0.395 & $0.483^{*}$ & -0.095 \\
\hline Microcystis sp2 & $-0.510^{*}$ & -0.281 & $0.486^{*}$ & 0.218 & 0.086 & $0.459^{*}$ & -0.25 \\
\hline Spirulina major & $-0.666^{* *}$ & -0.439 & $0.701^{* *}$ & 0.418 & 0.378 & 0.442 & 0.076 \\
\hline Spirulina princeps & -0.392 & -0.074 & 0.327 & 0.369 & 0.01 & 0.212 & -0.178 \\
\hline Spirulina subsalsa & -0.283 & 0.029 & -0.066 & -0.359 & -0.18 & 0.3 & 0.005 \\
\hline Glaucocystis sp. & $-0.691^{* *}$ & $-0.543^{* *}$ & $0.730^{* * *}$ & $0.610^{* *}$ & $0.450^{*}$ & $0.458^{*}$ & 0.144 \\
\hline Anabaena oscillarioides & $-0.617^{* *}$ & -0.385 & $0.533^{* *}$ & 0.305 & 0.203 & 0.279 & -0.276 \\
\hline Anabaena sp2 & 0.09 & 0.016 & -0.038 & -0.247 & -0.348 & $-0.485^{*}$ & $-0.534^{*}$ \\
\hline Anabaenopsis arnoldii & $-0.498^{*}$ & -0.358 & $0.569^{* *}$ & 0.205 & 0.035 & 0.338 & -0.394 \\
\hline Anabaenopsis sp2 & 0.119 & -0.059 & 0.047 & -0.155 & -0.329 & -0.351 & $-0.483^{*}$ \\
\hline Cylindrospermopsis sp. & -0.499 & -0.238 & 0.342 & 0.134 & 0.003 & 0.122 & -0.336 \\
\hline Nostoc sp. & $-0.673^{* *}$ & $-0.531^{* *}$ & $0.753^{* *}$ & $0.515^{*}$ & 0.386 & 0.461 & 0.004 \\
\hline Arthrospira maxima & -0.415 & -0.279 & 0.072 & $0.525^{*}$ & 0.08 & -0.172 & 0.064 \\
\hline Arthrospira sp2 & -0.281 & -0.208 & -0.083 & $0.562^{*}$ & 0.009 & -0.087 & 0.086 \\
\hline Lyngbya sp. & $-0.544^{*}$ & -0.176 & 0.404 & 0.297 & 0.066 & 0.239 & -0.275 \\
\hline Oscillatoria sancta & $-0.512^{*}$ & -0.365 & 0.49 & 0.349 & 0.132 & 0.389 & -0.257 \\
\hline Oscillatoria $\mathrm{sp} 2$ & -0.049 & 0.363 & -0.368 & 0.304 & -0.163 & -0.318 & 0.154 \\
\hline Merismopedia glauca & -0.184 & -0.127 & 0.253 & 0.109 & 0.234 & -0.043 & -0.304 \\
\hline Merismopedia sp2 & 0.171 & -0.18 & 0.115 & 0.093 & 0.263 & -0.017 & 0.095 \\
\hline
\end{tabular}


Fig. 3

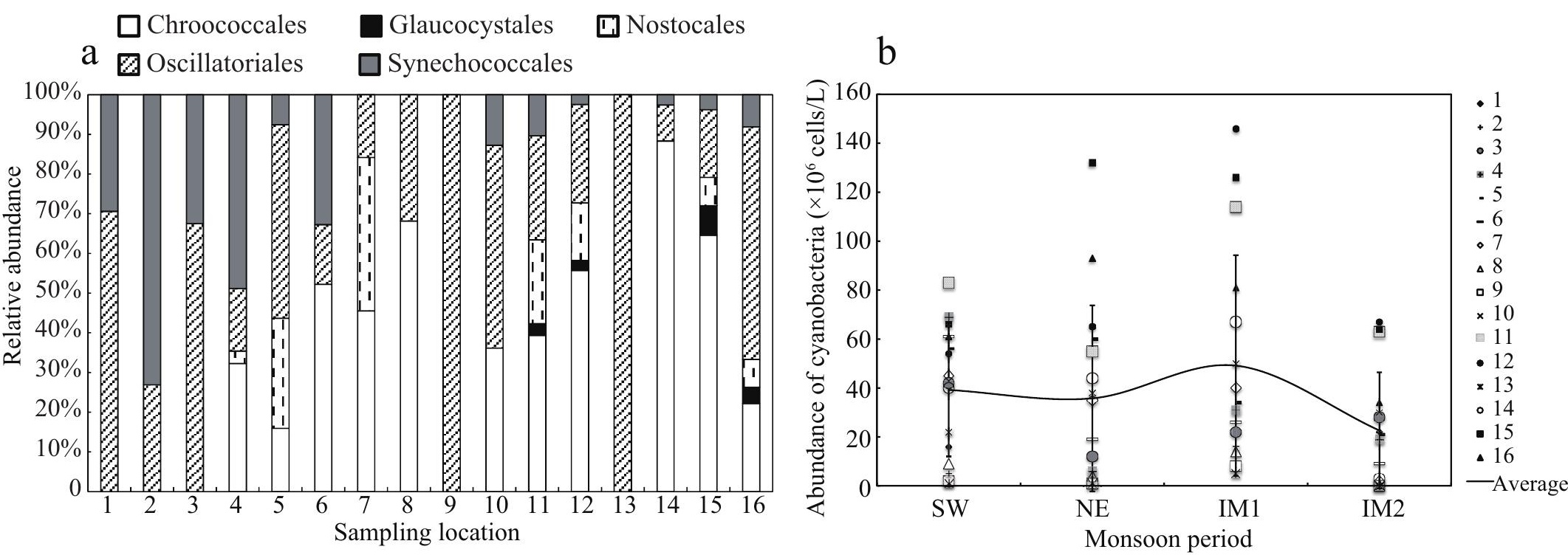


